\title{
Effect of Cooling Rate and Slag Modification on the Copper Matte in Smelting Slag
}

\author{
Xiang Gao ${ }^{1}$ (D) Zhuo Chen $^{1}$ (D) $\cdot$ Junjie Shi $^{2,3}$ (D) $\cdot$ Pekka Taskinen $^{2}$ (D) $\cdot$ Ari Jokilaakso $^{2}$ (D)
}

Received: 11 February 2020 / Accepted: 16 July 2020 / Published online: 31 July 2020

(C) The Author(s) 2020

\begin{abstract}
The amount of copper flash smelting slag has increased during the recent years along with an increasing slag-to-metal ratio. During slag tapping, some copper sulfide is mechanically entrained. As a result, it is necessary to recover copper matte from the slag by suitable methods. At present, the most common way is slow, controlled cooling in a transfer ladle. However, research on the detailed effects of slow cooling and the function of slag modification is rare. This paper described experiments that were performed at different cooling rates $\left(0.5,1.5,3\right.$, and $\left.7{ }^{\circ} \mathrm{C} / \mathrm{min}\right)$, with and without additive. A detailed characterization of the copper-rich phase and its particle size was subsequently made using SEM-EDS micrographs and image analysis software. With a decrease in cooling rate, the particle size of the copper-rich matte phase became larger. The addition of gypsum and carbon as a slag modifier affected the size of the copper-rich phase slightly, and its chemical composition was modified compared with the experiments without additive.
\end{abstract}

Keywords Slag cleaning $\cdot$ Ladle cooling $\cdot$ Copper matte $\cdot$ Image analysis

\section{Introduction}

Flash smelting technology has been widely applied in the smelting of copper sulfide concentrate because of its numerous merits, such as environmental friendliness, for example high $\mathrm{SO}_{2}$ fixing, and its low demand for external fossil fuels [1]. However, some copper matte is dispersed mechanically and entrained during slag tapping, and some copper dissolves in molten slag as cuprous oxide, resulting in a waste of resources [2]. It has been estimated that 2.2-3.0 metric tons of slag is produced for each ton of metal [3]; about 46 million tons of slag

\section{Clarification}

The designation of corresponding author is correct. Ari Jokilaakso is the corresponding author, even though this paper was submitted by first author Xiang Gao.

Ari Jokilaakso

ari.jokilaakso@aalto.fi

1 School of Energy Science and Engineering, Central South University, Changsha, Hunan Province, People's Republic of China

2 Department of Chemical and Metallurgical Engineering, School of Chemical Engineering, Aalto University, Espoo, Finland

3 Key Laboratory for Ecological Metallurgy of Multimetallic Mineral (Ministry of Education), Northeastern University, Shenyang 110819, China are produced annually in the copper industry [4]. Although the concentration of copper in the discarded slag is not large, typically about $0.8-1 \mathrm{wt} \%$, the total amount contained in slags is significant $[5,6]$. As a result, it is necessary to recover the copper in the slags by suitable methods in a separate slag cleaning step.

In the past few years, methods like flotation [7, 8], leaching $[9,10]$, and bioleaching [11] have been proposed. Milling and froth flotation methods are quite common when dealing with slow-cooled slags. Before flotation, the slag needs to be cooled in a controlled manner. There are multiple options for this, such as natural cooling, casting mill cooling, water quenching, and slow cooling in a ladle [12]. At present, the most popular method for cooling slag is slow cooling in a ladle, with typically $24 \mathrm{~h}$ cooling freely in air and $48 \mathrm{~h}$ cooling under water sprays [13].

This kind of recovery research has attracted some interest in the literature. Subramanian and Themelis [14] studied copper recovery by flotation and revealed the forms of copper in slags and the effect of the cooling rate. They measured the size distributions of copper particles in the Noranda process as a function of cooling rate. Jalkanen et al. [2] discussed the phenomena in copper slag solidification and plotted the particle size distribution of copper as well as copper matte particles in slowly cooled FSF (flash smelting furnace) and PS converter (Peirce-Smith) slags. Zhai et al. [15] studied the effects of the holding and cooling time on the crystallization and performance of copper slag, finding that it was possible to obtain a 
higher-grade copper slag concentrate at a cooling rate of $2{ }^{\circ} \mathrm{C} / \mathrm{min}$, and that a proper holding time was favorable for increasing the (molten) copper-containing phase. In order to achieve safe production and to optimize beneficiation, $\mathrm{Li}$ [16] established a slag ladle cooling system by testing the copper grade, the number of red dots (the middle of the copper slag is still liquid state), and the amount of solid bulk obtained by different slag types at various cooling rates. Wang [17] experimentally studied the influence of the cooling method and slow cooling on the copper grade and recovery in slag beneficiation, optimized the structure of the slag ladle, and designed an automatic monitoring system for measuring the surface temperature of the slag ladle. Mihajlović et al. [13] used COMSOL Multiphysics software for simulating the process of non-stationary slag cooling and experimentally tested the properties of slow-cooling slags. They verified that, under slow-cooling conditions, the generation of larger copper and copper sulfide particles was promoted, and thereby the particles could be better collected in the subsequent flotation to reduce copper losses in the waste slag.

In addition to testing the cooling time and controlling the cooling rate, some researchers have even considered using slag modification to increase copper recovery. Wang [18] studied the role of an additive, which was mainly waste biodiesel, in regulating the viscosity of the slag. Guo et al. [19] improved the beneficiation of copper and iron by modifying the viscosity of a molten copper slag. Huang [20] found that it was beneficial for copper recovery to maintain a cooling rate of less than $3{ }^{\circ} \mathrm{C} / \mathrm{min}$ in a temperature range of $1000{ }^{\circ} \mathrm{C}$ to $1250{ }^{\circ} \mathrm{C}$, in order to obtain a higher copper grade in slag beneficiation. Apart from the recovery of copper from copper slag, Yuki et al. [21] studied the recovery of magnetite from copper slag by slow cooling, finding that slow cooling and an oxidizing atmosphere, while holding the temperature constant, promoted the formation and crystal growth of magnetite.

However, few specific research studies on the effects of cooling rates on the particle size of copper or copper sulfide have been reported in the literature. The impact of slag modification by an additive, such as a gypsum-carbon mixture, is also unknown. As a result, a series of experiments was conducted on the particle size distribution of a copper-rich matte phase at different cooling rates, in order to better conduct the froth flotation process and to recover copper from slag with a higher yield.

\section{Materials and Methods}

\subsection{Materials}

\subsubsection{Copper Slag}

The copper slag for this research was obtained from an industrial copper flash smelting process. The color of the slag was black, and it was dried and ground into fine powder prior to the experiments. For each experiment, the initial slag mass was $13 \mathrm{~g}$.

As shown in Table 1 (the elements below $0.1 \mathrm{wt} \%$ have been removed), the main chemical components in the slag were $\mathrm{SiO}_{2}$ and iron oxides, containing $31.7 \mathrm{wt} \% \mathrm{SiO}_{2}$, $37.9 \mathrm{wt} \%$ total $\mathrm{Fe}$, and $12 \mathrm{wt} \% \mathrm{Fe}_{3} \mathrm{O}_{4}$. The total concentration of copper was $1.2 \mathrm{wt} \%$. The notations in Table 1 refer to the analytical method used for each substance.

The existing phases in the copper slag were also characterized by X-ray diffraction (XRD, PANalytical X'Pert Pro Powder, Almelo, the Netherlands) using Co $\mathrm{K} \alpha$ radiation at a scan rate of $2 \%$ min from $15^{\circ}$ to $90^{\circ}$ (acceleration voltage $40 \mathrm{kV}$, emission current $30 \mathrm{~mA}$ ).

Figure 1, showing the X-ray diffraction pattern of copper slag, reveals the main crystalline phases in the slag, i.e., fayalite $\left(2 \mathrm{FeO} \cdot \mathrm{SiO}_{2}\right)$ and magnetite $\left(\mathrm{Fe}_{3} \mathrm{O}_{4}\right)$. No copper phases were detected, mainly because of their small fraction in the slag and the resolution of X-ray diffraction (percentage of a phase should be over 5\%, otherwise it cannot be detected), but according to the ICP results, the slag is a typical flash smelting slag.

\subsubsection{Modifying Additives}

The additive used for modifying the slag was a mixture of gypsum anhydrate and carbon (as metallurgical coke with a $\mathrm{C}_{\text {fix }}$ of $88 \%$ ). Gypsum is a cost-effective and "green" source for lime since it is a common by-product and waste from various industrial processes in the chemical and power industries. If it can be used to improve copper recovery, it would be beneficial for general resource efficiency. During modification, the following chemical Reaction (1) was expected to occur at the slag cleaning temperatures [22]:

Table 1 Chemical composition of the copper slag (wt\%)

\begin{tabular}{lc}
\hline Substance & Concentration \\
\hline $\mathrm{Na}^{*}$ & 0.4 \\
$\mathrm{Mg}^{*}$ & 1.2 \\
$\mathrm{Al}^{*}$ & 2.3 \\
$\mathrm{~K}^{*}$ & 0.9 \\
$\mathrm{Ca}{ }^{*}$ & 0.8 \\
$\mathrm{Fe}(\text { tot })^{*}$ & 37.9 \\
$\mathrm{Cu}$ & 1.2 \\
$\mathrm{Zn}^{*}$ & 1.8 \\
$\mathrm{~S}($ tot $)$ with $\mathrm{S} / \mathrm{C} * *$ & 0.4 \\
$\mathrm{SiO}_{2} * * *$ & 31.7 \\
$\mathrm{Satmagan}^{* * * *}\left(\mathrm{Fe}_{3} \mathrm{O}_{4}\right)$ & 12 \\
\hline
\end{tabular}

*Inductively coupled plasma spectrometry; **combustion method; $* * *$ colorimetry; $* * * *$ magnetic balance for measuring $\mathrm{Fe}_{3} \mathrm{O}_{4}$ concentrations in iron silicate slags and iron concentrates 


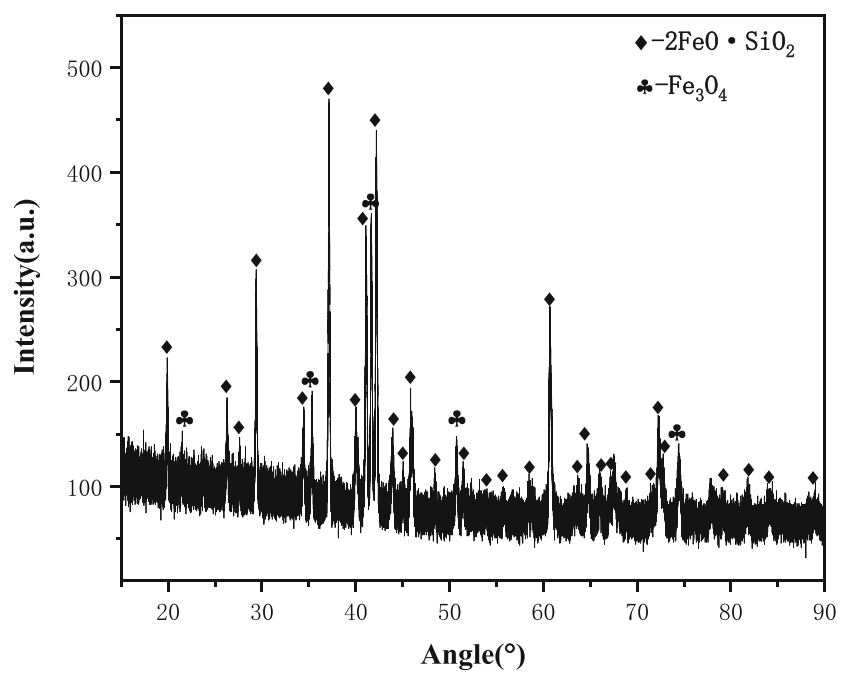

Fig. 1 X-ray diffraction pattern of the copper slag used

$$
\begin{aligned}
2 \mathrm{CaSO}_{4}(\mathrm{~s})+3 \mathrm{C}(\mathrm{s})= & 2 \mathrm{CaO}(\mathrm{s})+\mathrm{S}_{2}(\mathrm{~g}) \\
& +3 \mathrm{CO}_{2}(\mathrm{~g}) \Delta G^{\Theta}(\mathrm{kJ} / \mathrm{mol})
\end{aligned}
$$$$
=320.38-0.66 T\left({ }^{\circ} \mathrm{C}\right)
$$

$\Delta G^{\Theta}$ of Reaction (1) at $1300{ }^{\circ} \mathrm{C}$ is $-537.62 \mathrm{~kJ} / \mathrm{mol}$, which means Reaction (1) proceeds spontaneously to produce pure $\mathrm{CO}_{2}$ and $\mathrm{S}_{2}(\mathrm{~g})$. The $\Delta G^{\Theta}$ data were fitted from the HSC Chemistry [23] database.

For the experiment with additive, the target calcium oxide content in the slag was set to $1 \mathrm{wt} \%$ of the slag. As a result, the mass of lime needed was $0.13 \mathrm{~g}$. According to Reaction (1), the weight of anhydrous calcium sulfate and carbon required was $0.316 \mathrm{~g}$ and $0.055 \mathrm{~g}$, respectively. Before being added to the slag, gypsum (pro analysis grade, Riedel de Haën) was treated in an oven at $110^{\circ} \mathrm{C}$ in air for $20 \mathrm{~h}$, in order to remove its crystal water and thereby obtain calcium sulfate anhydrate.

\subsection{Apparatus}

The experimental apparatus used in this research is shown in Fig. 2 a. It comprised a vertical tube furnace (LTF 16/-/450; Lenton, Nottingham, UK) and a Eurotherm PID temperature controller (Eurotherm, Ashburn, VA, USA). The vertical furnace was equipped with four (4) silicon carbide (SiC) heating elements. The working tube was made of impervious pure alumina (AL 23; Friatec AG, Germany) with dimensions of $45 / 38 \mathrm{~mm}$ OD/ID. On top of the furnace, a furnace head with a water-cooling system included an inlet for an S-type Pt/Pt10Rh thermocouple (Johnson-Matthey Noble Metals, London, UK), inside a protective alumina sheath. Its thermovoltage was measured with a Keithley 2000 DMM multimeter (Keithley, Solon, OH, USA). A Pt100 resistant thermometer (SKS Group, Vantaa, Finland) was connected to the Keithley 2010 DMM multimeter to perform the cold- junction compensation. The temperature data were logged with LabVIEW software (National Instruments, Austin, TX, USA). A detail of the magnesium oxide crucible $(25 / 30 \mathrm{~mm}$ OD/H; Tateho Ozark Technical Ceramics, Webb City, Mo, USA) is shown on the right of Fig. 2 a. The crucible was used to hold the slag sample in the hot zone of the furnace with an alumina rod inserted through the water-cooled bottom of the furnace.

\subsection{Experimental Conditions and Procedures}

Before the experiments, the slag sample was weighed in a crucible. Then the temperature of the furnace hot zone was set to $1300{ }^{\circ} \mathrm{C}$. After that, the valve of the $\mathrm{N}_{2}$ (99.999 vol\%; AGA-Linde, Finland) line was opened to flush the working tube so that the atmosphere of the furnace was nitrogen during slag melting, homogenization, and cooling. Inserting the sample into the hot zone of the furnace was slow $(20 \mathrm{~min})$ because of the fragility of alumina and magnesia against thermal shocks. When the sample reached the hot zone, the holding time for the slag was 120 min to ensure that the slag would be molten and fully homogeneous when the cooling was started.

After the holding time, the program for controlling the cooling rate was switched on. Altogether, four cooling rates were studied $\left(0.5{ }^{\circ} \mathrm{C} / \mathrm{min}, 1.5{ }^{\circ} \mathrm{C} / \mathrm{min}, 3{ }^{\circ} \mathrm{C} / \mathrm{min}\right.$, and $7^{\circ} \mathrm{C} / \mathrm{min}$ ) in a temperature interval from 1300 to $1000{ }^{\circ} \mathrm{C}$. A schematic of the homogenization and cooling process is shown in Fig. 2 b. When the temperature reached $1000{ }^{\circ} \mathrm{C}$, the crucible with the slag was removed from the furnace hot zone within a 15 -min period in flowing $\mathrm{N}_{2}$, and then it was cooled in air to ambient temperature.

The cooled samples were first cut into four (4) pieces in the vertical direction and then cast in an epoxy resin. These pieces were ground and polished by traditional metallographic techniques. A carbon coating (Leica EM SCD050, Leica Microsystems, Wetzlar, Germany) was used after polishing to ensure sufficient conductivity. A Tescan MIRA 3 Scanning Electron Microscope (SEM; Tescan, Brno, Czech Republic) equipped with an UltraDry Silicon Drift Energy Dispersive X-ray spectrometer (EDS; Thermo Fisher Scientific, Waltham, MA, USA) and NSS microanalysis software were utilized to analyze the coated samples. The following parameters were used: accelerating voltage of $15 \mathrm{kV}$, beam current of $10.9 \mathrm{nA}$, and working distance of $20 \mathrm{~mm}$. The external standards used for EDS analyses were metallic $\mathrm{Al}$ (for $\mathrm{Al}, \mathrm{K} \alpha$ ), metallic As (for As, $\mathrm{L} \alpha$ ), metallic $\mathrm{Bi}$ (for $\mathrm{Bi}, \mathrm{M} \alpha$ ), calcite (for $\mathrm{Ca}, \mathrm{K} \alpha$ ), metallic $\mathrm{Co}$ (for $\mathrm{Co}, \mathrm{K} \alpha$ ), metallic $\mathrm{Cr}$ (for $\mathrm{Cr}, \mathrm{K} \alpha$ ), metallic $\mathrm{Cu}$ (for $\mathrm{Cu}$, $\mathrm{K} \alpha$ ), hematite (for $\mathrm{Fe}, \mathrm{K} \alpha$ ), sanidine (for $\mathrm{K}, \mathrm{K} \alpha$ ), metallic $\mathrm{Mg}$ (for $\mathrm{Mg}, \mathrm{K} \alpha$ ), tugtupite (for $\mathrm{Na}, \mathrm{K} \alpha$ ), metallic $\mathrm{Ni}$ (for $\mathrm{Ni}$, $\mathrm{K} \alpha$ ), quartz (for $\mathrm{O}, \mathrm{K} \alpha$ ), metallic $\mathrm{Pb}$ (for $\mathrm{Pb}, \mathrm{M} \alpha$ ), marcasite (for $\mathrm{S}, \mathrm{K} \alpha$ ), metallic $\mathrm{Sb}$ (for $\mathrm{Sb}, \mathrm{L} \alpha$ ), quartz (for $\mathrm{Si}, \mathrm{K} \alpha$ ), and metallic $\mathrm{Zn}$ (for $\mathrm{Zn}, \mathrm{K} \alpha$ ). For each phase, at least 10 points 
Fig. 2 a Schematic of the experimental furnace and a detail of the crucible. $\mathbf{b}$ Schematic of the homogenization and cooling processes in this research. c Principle of Image-Pro software for obtaining the phase dimensions and shapes

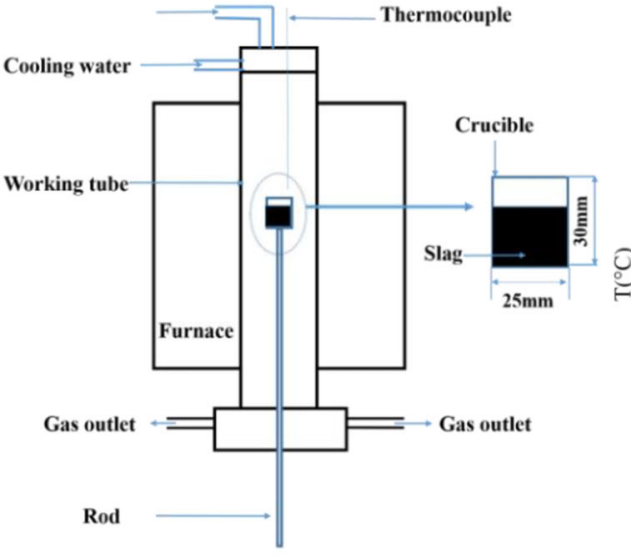

(a)

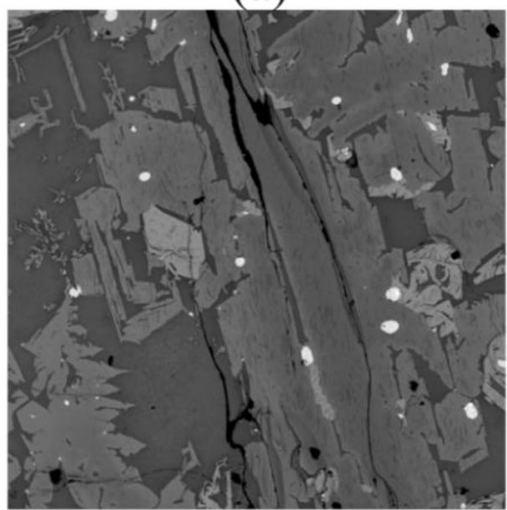

(Holging time: 120 minutes; holding temperature: $1300^{\circ} \mathrm{C}$ )

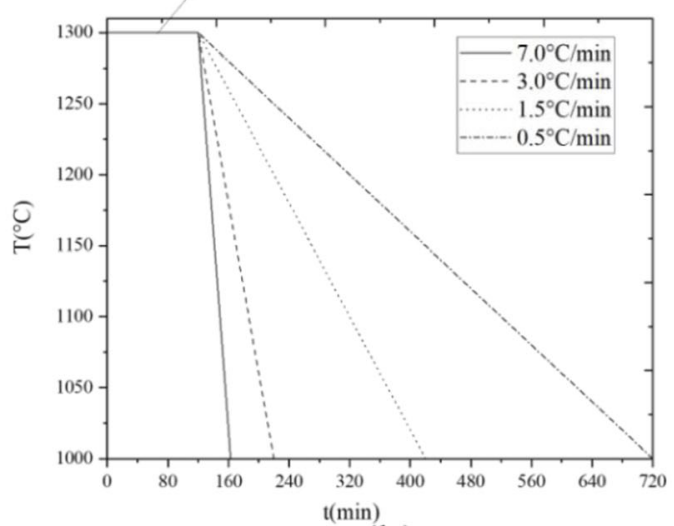

(b)

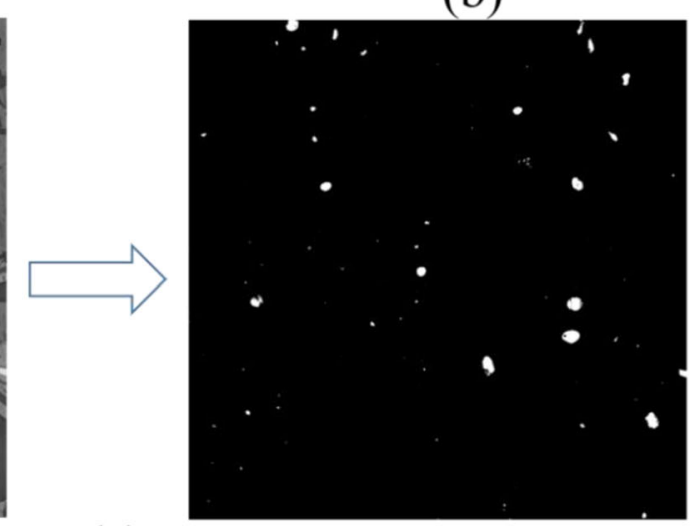

(c)

were randomly selected to ensure the homogeneity of the sample and accuracy of the averages. The Proza (Phi-RhoZ) matrix correction procedure was employed for raw data processing before normalizing the EDS results. EDS quantification in the Phi-Rho-Z mode is an elemental quantification method based on the matrix correction with the depth distribution function (Phi), mass density (Rho), and mean atomic number $(Z)$. Modern Phi-Rho-Z methods include fluorescence correction.

For each sample, around 100 micrographs were captured by SEM using a magnification of $\times 200$. In order to obtain the particle sizes of the copper-rich phase, Image-Pro Plus (vers. 6.0) software was used. Image-Pro Plus (Media Cybernetics Corporation, USA) is image analysis software capable of taking information from a picture and processing it by a variety of methods into numerical data.

Figure $2 \mathrm{c}$ shows how the software was adjusted to identify the phase(s) of interest: the one on the left is an SEM electron image, and the one on the right is its binary image for the copper-rich phase, after which the software was able to calculate the area fraction and diameter of the identified phases by pixel. The data can be exported for further analysis of the phase morphology. Since the shapes of many copper and matte droplets were not regular spheres or polygons, the definition of mean diameter $D_{\text {mean }}$ used in the study included measurements of the diameter $d_{i}$ at intervals of $2^{\circ}$, passing through the object centroid, as given in Eq. (2).

$D_{\text {mean }}=\left(d_{1}+d_{2}+\ldots \ldots+d_{181}\right) / 181$

\section{Results and Discussion}

\subsection{The Form of the Copper-Rich Phase in the Cooling Results}

Figure 3 shows the process used for analyzing one polished cross-section in the vertical direction in the crucible. The first picture reveals a macro view of the polished cross-section, while the second micrograph shows an overall view of it at low magnification, where the dark gray area (a) is the crucible wall, the light gray part (b) represents the copper slag, and the black section (c) is the epoxy resin.

The last micrograph on the right in Fig. 3 shows the four typical phases in the slag using four different shades. According to the EDS results shown in Table 2 (elements below $0.1 \mathrm{~mol} \%$ were removed), area 1 shown in medium 


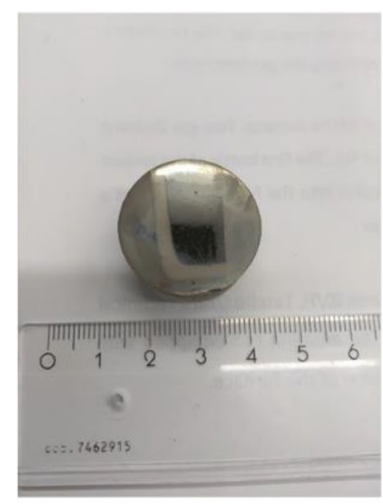

(a)

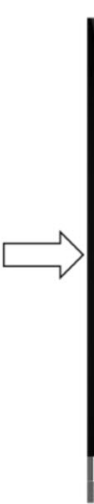

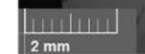

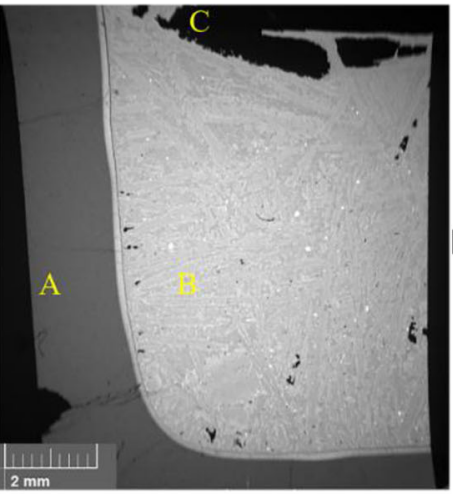

(b)

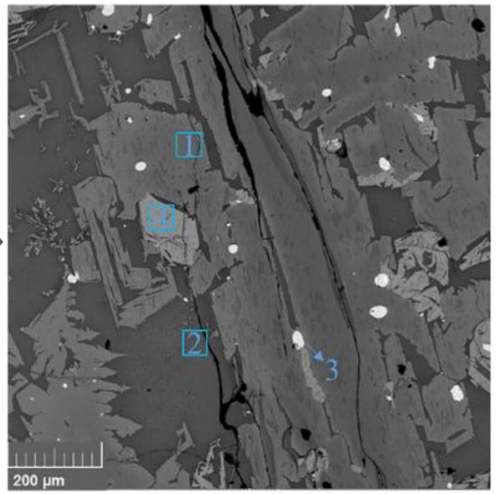

(c)

Fig. 3 Typical analysis process of the polished copper slag cross sections: (a) macrograph of the sectioned crucible, (b) vertical cross-section of the crucible, and (c) microstructure of the slag

gray belongs to crystalline fayalite $2 \mathrm{FeO} \cdot \mathrm{SiO}_{2}$ with the element ratio of $(\mathrm{Fe}+\mathrm{Mg})$ to $\mathrm{Si}$ equal to $2: 1(\mathrm{~mol} / \mathrm{mol})$, and area 2 with a dark gray color is the glassy intergranular phase with an Fe to $\mathrm{Si}$ atom ratio of 1:2. The brightest phase 3 is copperrich sulfide matte, with a $\mathrm{Cu}$ to $\mathrm{S}$ atom ratio equal to approximately 2:1. Last, the gray part 4 belongs to magnetite $\mathrm{Fe}_{3} \mathrm{O}_{4}$. As a result, attention in this study was paid to the brightest phase (the copper matte-copper phase fields), especially regarding the development of the size and size distributions of the phases in different cooling conditions. During the cooling without additive, the sulfide was formed by physical separation when its solubility product was exceeded, and by growth of the droplets. Some metallic copper was also formed in the final solidification when magnetite was formed $[2,14]$.

Figure 4 compares the copper-rich phases after experiments at different cooling rates and slags with and without the slag-modifying gypsum + coke additive. As can be seen, there are four phases in each micrograph. Each phase has been checked by EDS as described above, finding that only the bright phases are rich in copper. The detailed results for the bright phase areas can be found in Table 3 .

As shown in Table 3, the compositions were quite similar for all the bright phases (1-4) in the samples without additive at different cooling rates, and the main elements were $\mathrm{Cu}$ and $\mathrm{S}$, with average fractions of $67 \mathrm{~mol} \%$ and $23 \mathrm{~mol} \%$, respectively. However, for the bright phases in the modified sample with added gypsum and carbon (\#5), the main elements were
$\mathrm{Cu}, \mathrm{Fe}$, and $\mathrm{S}$. This means that in slag modification, the iron dissolved into copper sulfide or the sulfide composition was closer to that of the tapped matte. There were no other differences in the copper-rich phases between the slag without additive and the slag with additive.

\subsection{Effect of the Cooling Rate on the Copper/Copper Matte Particle Size}

As clearly shown in the line chart of Fig. 5 a, with an increase in the cooling rate from 0.5 to $7{ }^{\circ} \mathrm{C} / \mathrm{min}$, the percentage of small matte size fractions shows a sharp rise, whereas the low cooling rate demonstrates a lower rise and a larger average diameter. For example, at a cooling rate of $0.5^{\circ} \mathrm{C} / \mathrm{min}$, the fraction of the matte droplets lower than $5 \mu \mathrm{m}$ in diameter is $55 \%$, which is in sharp contrast with the percentage of approx. $72 \%$ at a cooling rate of $7{ }^{\circ} \mathrm{C} / \mathrm{min}$. Again, at the cooling rate of $7{ }^{\circ} \mathrm{C} / \mathrm{min}$, the fraction of matte particles with a diameter of lower than $15 \mu \mathrm{m}$ is nearly $100 \%$, which means that almost all the particles were smaller than $15 \mu \mathrm{m}$, whereas at a cooling rate of $0.5^{\circ} \mathrm{C} / \mathrm{min}$, particles smaller than $15 \mu \mathrm{m}$ account for about $90 \%$.

According to the bar chart in Fig. 5 a, a similar conclusion can be made based on the matte droplet sizes. The matte particle diameters were divided into the following size classes: $1 \sim 2 \mu \mathrm{m}, 2 \sim 3 \mu \mathrm{m}, 3 \sim 4 \mu \mathrm{m}, 4 \sim 5 \mu \mathrm{m}, 5 \sim 10 \mu \mathrm{m}, 10 \sim 20 \mu \mathrm{m}$, and $20 \sim 50 \mu \mathrm{m}$. Matte particles with a diameter over $50 \mu \mathrm{m}$ were rare and, therefore, omitted from the analysis. For the first

Table 2 EDS results of the typical phase areas in Fig. 3(c) (mol\%)

\begin{tabular}{lllllllllllllllll}
\hline Area & $\mathrm{O}$ & $\mathrm{Na}$ & $\mathrm{Mg}$ & $\mathrm{Al}$ & $\mathrm{Si}$ & $\mathrm{S}$ & $\mathrm{K}$ & $\mathrm{Ca}$ & $\mathrm{Fe}$ & $\mathrm{Co}$ & $\mathrm{Ni}$ & $\mathrm{Cu}$ & $\mathrm{Zn}$ & $\mathrm{As}$ & $\mathrm{Pb}$ & $\mathrm{Bi}$ \\
\hline 1 & 54.6 & 0 & 2.1 & 0.1 & 14.6 & 0.04 & 0 & 0.1 & 27.4 & 0.3 & 0 & 0 & 0.7 & 0.03 & 0 & 0 \\
2 & 58.9 & 1.2 & 0.3 & 5.1 & 21.2 & 0.1 & 1.2 & 2.03 & 9.2 & 0.1 & 0 & 0.01 & 0.7 & 0.1 & 0 & 0.02 \\
3 & 0 & 0 & 0 & 0 & 0 & 29.7 & 0.03 & 0.01 & 4.8 & 0 & 0.2 & 64.1 & 0 & 0 & 0.7 & 0.5 \\
4 & 25.1 & 0 & 0.12 & 2.4 & 0.3 & 0.1 & 0 & 0.02 & 69.39 & 0.88 & 0 & 0 & 1.6 & 0 & 0 & 0 \\
\hline
\end{tabular}



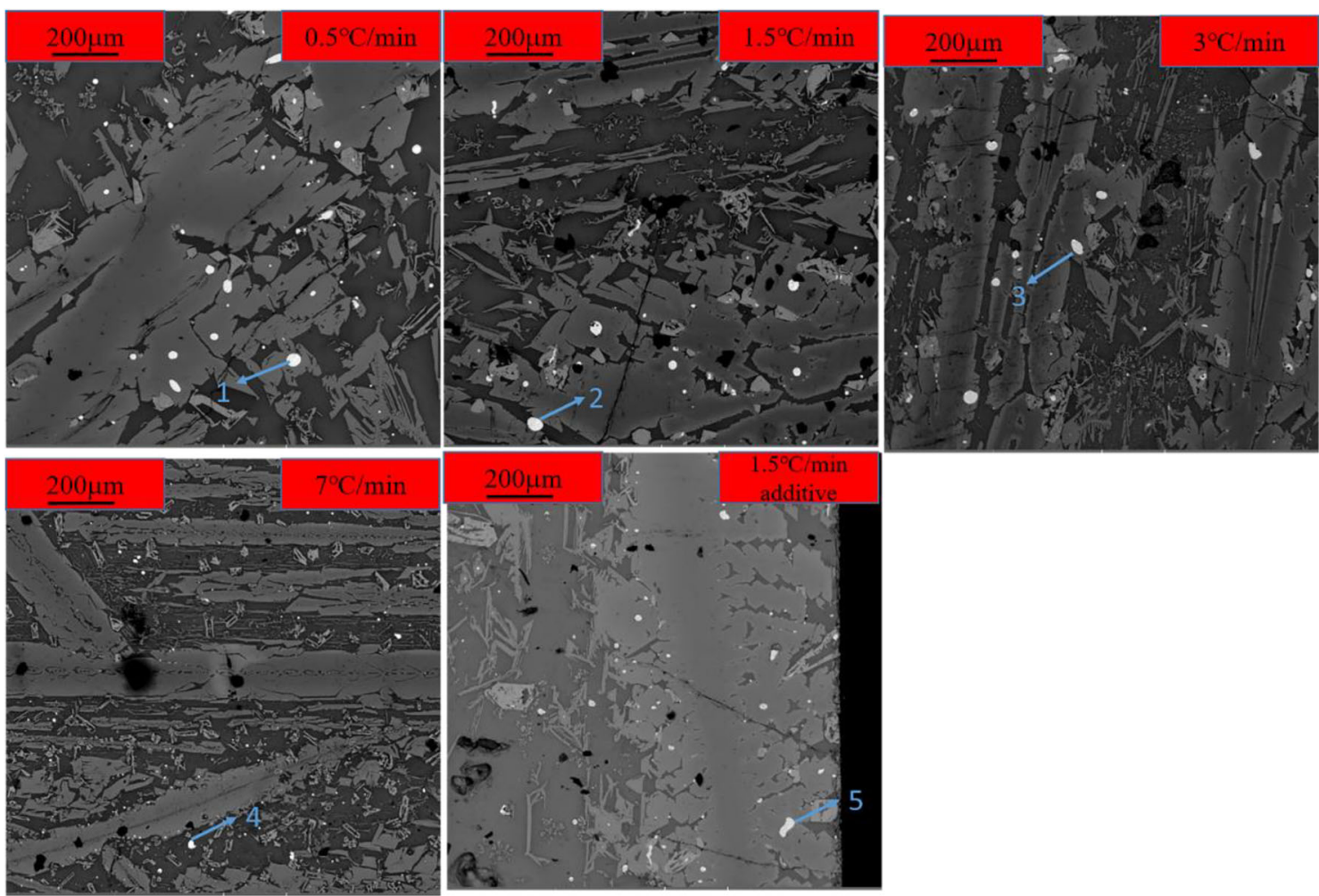

Fig. 4 A comparison of the morphologies of the copper-rich phases in different conditions. The EDS analyses of the labeled phases are given in Table 3

three size groups, with the decrease in cooling rate, their percentages decreased systematically, while for the last three size groups, the opposite trend was revealed. This clearly confirmed that larger copper matte/copper particles were generated at low slag cooling rates.

In Fig. 5 b, a plot was obtained from the present image analysis data with the slag cooling rate and copper matte/ copper droplet diameter as abscissa and ordinate, respectively. The solid line shows the average matte droplet size as a function of cooling rate and the dotted line depicts the maximum droplet size observed at each cooling rate. From the line showing the average droplet size, it is clear that, with a decrease in cooling rate, the average diameter of the copper/matte phase became larger ( $3.6 \mu \mathrm{m}$ to $5.8 \mu \mathrm{m})$. In addition, at cooling rates lower than $3{ }^{\circ} \mathrm{C} / \mathrm{min}$, the diameter grew dramatically with the reduction of the cooling rate $(4 \mu \mathrm{m}$ to $5.8 \mu \mathrm{m})$. When the cooling rate was higher than $3{ }^{\circ} \mathrm{C} / \mathrm{min}$, the rate of growth was smaller $(4 \mu \mathrm{m}$ to $3.6 \mu \mathrm{m})$. For the line describing the

Table 3 EDS results of several areas in different conditions (mol\%)

\begin{tabular}{lllllllllllll}
\hline Area & $\mathrm{Mg}$ & $\mathrm{Al}$ & $\mathrm{S}$ & $\mathrm{K}$ & $\mathrm{Ca}$ & $\mathrm{Fe}$ & $\mathrm{Ni}$ & $\mathrm{Cu}$ & $\mathrm{As}$ & $\mathrm{Sb}$ & $\mathrm{Pb}$ & $\mathrm{Bi}$ \\
\hline 1 & 3.5 & 0 & 25.3 & 0.02 & 0.1 & 3.1 & 0.1 & 65.5 & 1.0 & 0.1 & 1.0 & 0.3 \\
2 & 1.2 & 0 & 27.6 & 0 & 0.04 & 5.0 & 0.2 & 64.3 & 0 & 0.1 & 1.1 & 0.3 \\
3 & 0 & 0 & 18.0 & 1.2 & 1.2 & 2.7 & 0.1 & 69.2 & 5.6 & 0.7 & 1.2 & 0.1 \\
4 & 0 & 0 & 21.0 & 1.5 & 0.8 & 5.6 & 0.2 & 68.9 & 0 & 0.2 & 1.3 & 0.5 \\
5 & 0 & 0.7 & 22.3 & 1.3 & 0.2 & 15.4 & 1.0 & 57.0 & 0 & 0.1 & 1.4 & 0.6
\end{tabular}

maximum droplet diameter, except for the cooling rate of $1.5^{\circ} \mathrm{C} / \mathrm{min}$, the diameter was the largest $(175 \mu \mathrm{m})$ at the slowest cooling rates. The overall trend that an increase in the cooling rate will lead to a smaller particle size was similar.

To sum up, a decrease in the slag cooling rate extends the time for the copper and matte droplets to grow and settle before the final solidification of the silicate slag matrix. This temperature range $\left(1000{ }^{\circ} \mathrm{C}-1300{ }^{\circ} \mathrm{C}\right)$ should be controlled carefully for better recovery of copper in the subsequent milling and flotation steps. In addition, based on the current observations, it can be concluded that when the cooling rate was less than $3{ }^{\circ} \mathrm{C} / \mathrm{min}$, the effect of cooling control was more evident.

\subsection{Effect of Additive on the Particle Size}

As mentioned before, the tested amount of additive in the slag modification was small, just $1 \mathrm{wt} \% \mathrm{CaO}$ of the total slag weight. According to Fig. 6, the effect of additive was not significant in terms of the matte droplet size. Although the impact was small, the simultaneous addition of gypsum and carbon in fact systematically increased the size of the copperrich phase. In the copper/matte droplet size classes smaller than $12 \mu \mathrm{m}$, the percentage in the modified slag was slightly smaller, whereas in the size classes larger than $12 \mu \mathrm{m}$, the matte size fractions in the modified slags were larger. The results are summarized in Fig. 6. 
(a)
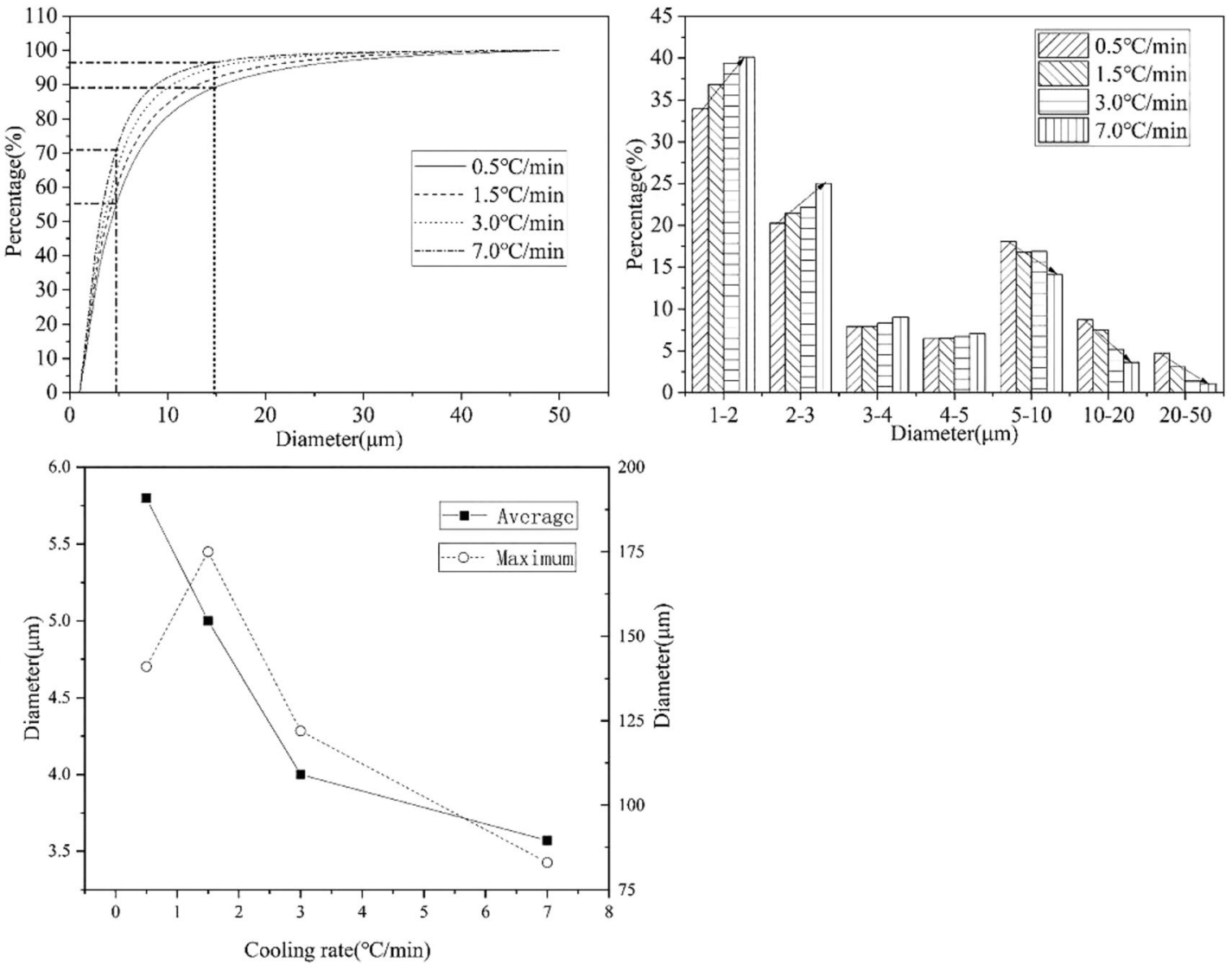

Fig. 5 a Effect of cooling rate on the cumulative particle size distribution and on the fractions of different size classes. b Change in the matte/copper droplet diameter with the slag cooling rate

The bar chart in Fig. 6 shows a similar trend to that for different cooling rates, i.e., the normal slag accounts for a larger proportion in the small droplet size $(1 \mu \mathrm{m} \leq D \leq$ $3 \mu \mathrm{m}$ ), and the sample with modified slag induced slightly larger matte fractions in the larger diameter classes where the copper/matte droplet diameter was between 3 and $20 \mu \mathrm{m}$. The effect was, however, significant in the mass of copper present in the large droplet fractions. However, the small number of very large droplets, $20-50 \mu \mathrm{m}$, may have distorted the results shown in Fig. 6.

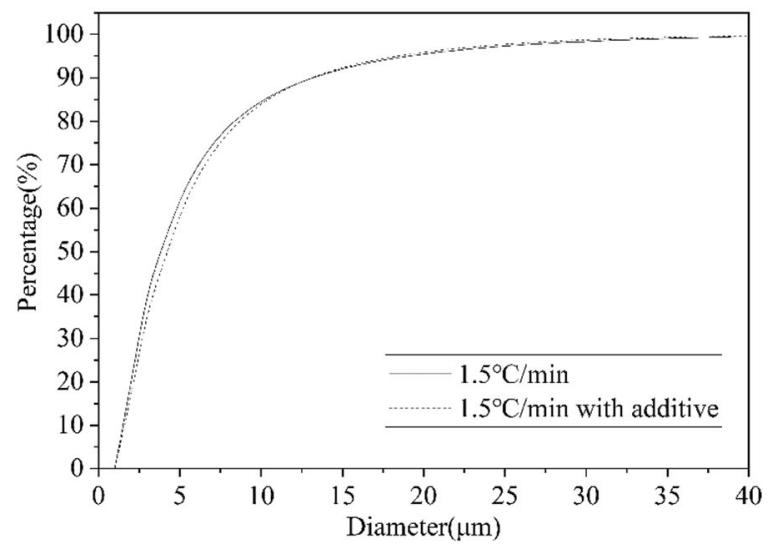

By using the additive, the oxygen partial pressure of the system was reduced and the sulfur potential of the system was increased because of the formation of sulfur vapor in Reaction (1). The main oxide phase in the initial slag was magnetite and the SEM micrographs indicated that $\mathrm{Fe}_{3} \mathrm{O}_{4}$ was reduced to $\mathrm{FeO}$ and magnetite was no longer present in the solidified slag. This may have reduced the viscosity of the slag and thus promoted the separation of matte and slag. Reaction (1) produces gaseous $\mathrm{CO}_{2}$ and the bubbles that stir the slag and it is thus possible to promote clustering of the fine matte and

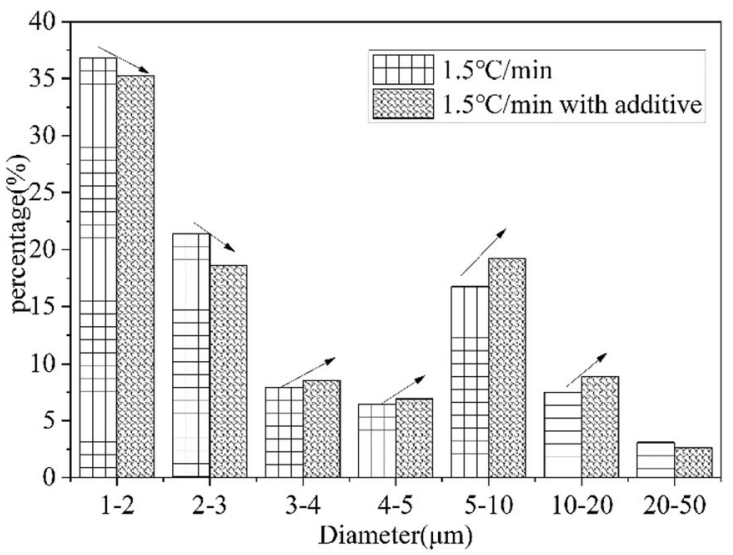

Fig. 6 Comparison of particle sizes after cooling at $1.5^{\circ} \mathrm{C} / \mathrm{min}$ with and without modification 
copper droplets, increasing their particle size, which improves settling and ultimately reduces the amount of copper dispersed in the discard slag. However, more evidence needs to be collected by means of further experiments over a wider range of operational conditions before firm conclusions can be made about the feasibility of slag modification using waste gypsum and, for example, biocoke reductant.

\section{Conclusions}

An investigation was made of the effects of the cooling rate and slag modification by simultaneous additions of gypsum and carbon on copper and copper matte particle sizes in an industrial copper matte smelting slag. The development of the copper-rich phase was quantified using image analysis. The following conclusions were made based on the statistical treatment of a large number of SEM micrographs and the EDS phase composition data:

(1) The decrease in cooling rate in a temperature range from 1300 to $1000{ }^{\circ} \mathrm{C}$ increased the average size of the copper-rich droplets in the slag, which is beneficial for the recovery of copper in the subsequent slag cleaning by flotation. Therefore, in industrial operations, it is beneficial to cool the slag at a low rate before final solidification of the iron silicate slag at about $1150{ }^{\circ} \mathrm{C}$.

(2) The effect of slag modification on the copper-rich phase was evident even on a level of $1 \mathrm{wt} \% \mathrm{CaO}$ addition. For slags without modification, the copper/matte phase mainly consisted of copper and sulfur, whereas in the modified slag, the copper-rich phase also contained a significant fraction of iron. A certain proportion of iron from the slag was dissolved in the matte.

(3) With the simultaneous addition of gypsum and carbon to the slag, the copper/matte droplet size increased slightly in all size classes. Since the proportion of additive was relatively small, more experimental data need to be collected before making firm conclusions about the feasibility of this new technique.

Acknowledgments The authors wish to acknowledge the contribution of Central South University and Aalto University for providing the sponsorship, equipment, and material for this study. This study utilized the Academy of Finland's RawMatTERS Finland Infrastructure (RAMI) housed jointly at Aalto University, GTK, and VTT in Espoo.

Authors' Contributions Xiang Gao conducted the experiment and wrote the paper.

Zhuo Chen provided the experiment methodology and edited the paper.

Junjie Shi helped with the experiment and analysis and edited the paper.

Pekka Taskinen provided the experiment methodology and edited the paper.
Ari Jokilaakso provided the experiment methodology and edited the paper.

Funding Information Open access funding provided by Aalto University. The research was sponsored by the Postgraduate Exchange Program of the Central South University.

Availability of Data and Material Available upon request.

\section{Compliance with Ethical Standards}

Conflict of Interest The authors declare that they have no conflict of interest.

Code Availability No code was used in this paper.

Open Access This article is licensed under a Creative Commons Attribution 4.0 International License, which permits use, sharing, adaptation, distribution and reproduction in any medium or format, as long as you give appropriate credit to the original author(s) and the source, provide a link to the Creative Commons licence, and indicate if changes were made. The images or other third party material in this article are included in the article's Creative Commons licence, unless indicated otherwise in a credit line to the material. If material is not included in the article's Creative Commons licence and your intended use is not permitted by statutory regulation or exceeds the permitted use, you will need to obtain permission directly from the copyright holder. To view a copy of this licence, visit http://creativecommons.org/licenses/by/4.0/.

\section{References}

1. Wang S, Davenport W, Yao S, Walters G, Gonzales T, Siegmund A, George D (2019) Copper smelting: 2019 World Copper Smelter Data. In: Copper 2019 International Conference, Montreal, Canada. CIM MetSoc

2. Jalkanen H, Vehvilãinen J, Poijãrvi J (2010) Copper in solidified copper smelter slags. Scand J Metall 32(2):65-70

3. Shi C, Meyer C, Behnood A (2008) Utilization of copper slag in cement and concrete. Resour Conserv Recycl 52(10):1115-1120. https://doi.org/10.1016/j.resconrec.2008.06.008

4. Group ICS (2019) The world copper factbook. Lisbon, Portugal (cited on February 2020 as: http://www.icsg.org/index.php?option= com_content\&task=view\&id=2\&Itemid=78). Accessed 2 Feb 2020

5. Heo JH, Kim B-S, Park JH (2013) Effect of $\mathrm{CaO}$ addition on iron recovery from copper smelting slags by solid carbon. Metall Mater Trans B 44(6): 1352-1363

6. Shibayama A, Takasaki Y, William T, Yamatodani A, Higuchi Y, Sunagawa S, Ono E (2010) Treatment of smelting residue for arsenic removal and recovery of copper using pyro-hydrometallurgical process. J Hazard Mater 181(1-3):1016-1023

7. Roy S, Rehani S (2015) Flotation of copper sulphide from copper smelter slag using multiple collectors and their mixtures. Int J Miner Process 143:S0301751615300168

8. Bruckard WJ, Somerville M, Hao F (2004) The recovery of copper, by flotation, from calcium-ferrite-based slags made in continuous pilot plant smelting trials. Miner Eng 17(4):495-504

9. Li Y, Perederiy I, Papangelakis VG (2008) Cleaning of waste smelter slags and recovery of valuable metals by pressure oxidative leaching. J Hazard Mater 152(2):607-615

10. Urosevic DM, Dimitrijevic MD, Jankovic ZD, Antic DV (2015) Recovery of copper from copper slag and copper slag flotation 
tailings by oxidative leaching. Physicochem Probl Mineral Process 51(1):73-82. https://doi.org/10.5277/ppmp 150107

11. Panda S, Mishra S, Rao DS, Pradhan N, Mohapatra U, Angadi S, Mishra BK (2015) Extraction of copper from copper slag: mineralogical insights, physical beneficiation and bioleaching studies. Korean J Chem Eng 32(4):667-676. https://doi.org/10.1007/ s11814-014-0298-6

12. Hengfeng $Z$ (2010) Process research and production practice of copper slag beneficiation. Paper presented at the Proceedings of the National Symposium on Mine Concentration Production, Xuzhou: China University of Mining and Technology

13. Mihajlović A, Kamberović Ž, Korać M, Gavrilovski M, Jovanović N (2015) The effect of primary copper slag cooling rate on the copper valorization in the flotation process. Metall Mater Eng 21(2):127-141

14. Subramanian KN, Themelis NJ (1972) Copper recovery by flotation. JOM 24(4):33-38

15. Qilin Z, Runqing L, Chen W, Wei S, Yue Y (2019) Effect of insulation slow cooling on crystallization performance of copper slag and copper flotation. Conserv Utilization Mineral Resour 39(03):75-80

16. Siyong L (2017) Establishment of cooling system for copper smelting slag ladle. Non-Ferrous Metals (smelting part) 11:42-45

17. Yonghong W (2016) Research and application of copper slag cooling process. Nonferrous Metall Energy Saving 32(01):14-16
18. Hua W, Bo L, Hao Z, Yonggang W, Jianhang H (2016) Application of an additive for regulating the viscosity of slag during the pyrometallurgical process of non-ferrous metals (Patent number: CN2016106 80584.0 aceepted October 26 2016)

19. Guo Z, Deqing Z, Jian P, Tengjiao W, Feng Z (2016) Improving beneficiation of copper and Iron from copper slag by modifying the molten copper slag. Metals 6(4):86-102

20. Hongjun H (2012) Study on new flotation process for controlling crystal phase of copper-containing slag. Non-Ferrous Metals (concentration part) 6(06):16-21

21. Tsunazawa Y, Liu C, Toi R, Okura T, Tokoro C (2018) Crystal formation and growth by slow cooling for recovery of magnetite particles from copper smelting slag. Mineral Process Ext Metall 128(4):248-255. https://doi.org/10.1080/25726641.2018.1483793

22. Longgong X, Zhihong L, Rui C, Shuheng C, Yiwang Z, Feng Y, Shufeng Y (2019) A new type method of gypsum to strengthen the recovery of valuable metals in copper slag (Patent number: 201910440146.0. accepted May 24, 2019)

23. Roine A (2019) HSC chemistry for windows, vers.9.2.6 (Pori, Finland: Outotec Research. www.hsc-chemistry.com. Accessed on 15 January 2020

Publisher's Note Springer Nature remains neutral with regard to jurisdictional claims in published maps and institutional affiliations. 